\title{
Powder Fruit Bit (Beta Bulgaris) To Decrease Of Blood Pressure In Hypertension Patients
}

\author{
Sari Pratiwi Apidianti*, Emi Yunita \\ Madura Islamic University, Indonesia \\ *saripratiwie86@gmail.com
}

\begin{abstract}
Hypertension is often referred to as a "silent killer" because often people with hypertension for years are not Feeling a disturbance or symptom and without realizing it, the patient has experienced complications in vital organs such as the heart, brain, and kidneys. As we age, physiological functions decrease due to the aging process (degenerative phase) so that noncommunicable diseases such as hypertension often appear. The research objective was to analyze Beetroot Powder (Beta Bulgaris) Against Blood Pressure Decrease in Hypertension Patients.

The study design used a pre-experimental, one group pre-post test design. The population is all people with hypertension in the Coastal Area, Pademawu District, Pamekasan Regency, East Java Province. Subjects were 40 respondents using total sampling. The independent variable was beet powder (Beta Bulgaris) and the dependent variable was blood pressure. Data were collected using a digital tensimeter and analyzed with Wilcoxon $(\alpha<0.05)$. The results of the study had an average systolic blood pressure of $165 \mathrm{mmHg}$ and a diastolic of $93 \mathrm{mmHg}$. The difference in systolic blood pressure results $\rho=0.000$ (Negative Rank: 28, Positive Rank: 6, Ties: 6) diastolic results $\rho=0.293$. The results of the analysis $\rho<\alpha$, then there is a significant difference in systolic blood pressure before and a container of Beetroot Powder (Beta Bulgaris) Against Decreasing BloodHypertensive Patients Blood

Pressure can be decreased by giving beets (Beta Bulgaris) and is effective in decreasing systolic blood pressure at hypertensive sufferers.
\end{abstract}

Keywords : Beta Bulgaris, Hypertension, Blood Pressure, Hypertensive Patients 


\section{STRADA Jurnal Ilmiah Kesehatan}

DOI: $10.30994 /$ sjik.v9i2.422

ISSN: 2252-3847 (print); 2614-350X (online)

Vol.9 No.2 November 2020 Page.1033-1040

\section{BACKGROUND}

Hypertension has become a disease that kills many people in developed and developing countries for the last eight decades. Hypertension is a circulatory system disorder that causes an increase in blood pressure above normal values, which exceeds 140/90 mmHg. Based on etiology, hypertension can be divided into 2, namely; primary hypertension and secondary hypertension. Hypertension is known as the "silent killer" because often people with hypertension do not feel a disorder or symptom (Endang, 2014). Hypertension often causes changes in blood vessels that can lead to higher blood pressure. Poor management of hypertension can cause morbidity and mortality due to cardiovascular complications (Padila, 2010). Hypertension occurs in response to increased cardiac output or increased peripheral pressure, factors that affect hypertension, namely: age, gender, obesity, family history, smoking, exercise (Oktavianus, 2014).

The World Health Organization (WHO) noted that in 2012 there were at least 839 million cases of hypertension, estimated to be 1.15 billion in 2025 or around $29 \%$ of the world's total population, where more sufferers were women (30\%) than men (29\%). ). About $80 \%$ of the increase in cases of hypertension occurs mainly in developing countries. The prevalence of hypertension in Indonesia reaches $31.7 \%$ of the population aged 18 years and over. Of that amount, $60 \%$ of people with hypertension experience heart disease, kidney disease, and blindness. Hypertension as the third cause of death after stroke and tuberculosis accounts for $6.8 \%$ of the proportion of causes of death at all ages in Indonesia (Riskesdas, 2010).

Hypertension is a condition when a person experiences an increase in blood pressure above normal which results in morbidity and mortality (Reny, 2010). Hypertension occurs due to an increase in blood pressure in the arteries which usually occurs in several ways, namely when the heart pumps stronger so that more fluid flows every second which results in the arteries losing their flexibility and becoming stiff so that they cannot expand when the heart pumps blood through the arteries. Blood that is forced through narrow arteries will cause an increase in blood pressure (Endang, 2014). Hypertension is an asymptomatic condition in which high blood pressure in the arteries increases the risk of cardiovascular-related diseases such as stroke, heart attack, heart failure, and is a major cause of chronic kidney failure. Other consequences caused by high blood pressure are bleeding in the clear membranes, rupture of blood vessels in the brain, and paralysis (Sutanto, 2010).

Continuous increase in blood pressure requires further management. The management of hypertension aims to prevent morbidity and mortality due to cardiovascular complications associated with achieving and maintaining blood pressure below 140/90 $\mathrm{mmHg}$. There is 3 management of hypertension, namely drug-free therapy, drug therapy, and follow-up. stroke. while the rest suffer from heart disease, kidney failure, and blindness (Riskesdas 2018). Beet is a tuber plant that is widely used for natural medicine. The benefits of beets that can be consumed by boiling, steaming, roasting, juicing, or eating raw are also numerous. However, beets are not a type of fruit, but rather dark red tubers that grow in the soil. The benefits of beets can be obtained from the nutrients contained therein which can lower blood pressure with a large antioxidant response.

\section{METHODS}

The research was carried out on the Pemekasan Regional Coastal Coast. The research method is experimental with a pre-experimental approach (pretest post-test 


\section{STRADA Jurnal Ilmiah Kesehatan}

DOI: $10.30994 /$ sjik.v9i2.422

ISSN: 2252-3847 (print); 2614-350X (online)

Vol.9 No.2 November 2020 Page.1033-1040

design). The study population was all hypertensive patients, the sample was part of the mother. The side technique uses positive sampling. The independent variable of the study was the provision of powdered beetroot. The dependent variable is blood pressure. The research results were collected and coded. Statistical test using the Willcoxon test with a $<0.005$. The first step of the research procedure was through an ethical test, then the researcher performed apperception with students in collecting data. The data collection process is that the researcher gives informed consent to the patient or family to be signed if the client agrees to be the research respondent. Furthermore, the researchers gave beetroot powder preparations to patients with hypertension and then looked at its effectiveness after 3 days.

\section{RESULTS}

Table 1. Characteristics of respondents based on Gender

\begin{tabular}{llll}
\hline No & Gender & Frequency & Percentage \\
\hline 1 & Male & 2 & 5.0 \\
\hline 2 & Female & 38 & 95.0 \\
\hline & Total & 40 & 100.0 \\
\hline
\end{tabular}

Based on the table above, it is found that most respondents have female gender as many as 38 respondents (95\%)

Table 2. Characteristics of respondents based on Age

\begin{tabular}{llll}
\hline No & Age & Frequency & Percentage \\
\hline 1 & $50-59$ years & 16 & 40.0 \\
\hline 2 & $>60$ years & 24 & 60.0 \\
\hline & Total & 40 & 100.0 \\
\hline
\end{tabular}

Based on the table above, it is found that most respondents have age $>60$ years as many as 24 respondents $(60 \%)$

Table 3. Characteristics of respondents based on Occupation

\begin{tabular}{llll}
\hline No & Occupation & Frequency & Percentage \\
\hline 1 & Domestic Helper & 34 & 85.0 \\
\hline 2 & Trader & 2 & 5.0 \\
\hline 3 & Farmers & 4 & 10.0 \\
\hline & Total & 40 & 100.0 \\
\hline
\end{tabular}

Based on the table above, it is found that most respondents have a job as a domestic helper as many as 34 respondents $(85 \%)$

Table 4. Characteristics of respondents based on Education

\begin{tabular}{llll}
\hline No & Education & Frequency & Percentage \\
\hline 1 & Not attending school & 29 & 72.5 \\
\hline 2 & Elementary school & 11 & 27.5 \\
\hline & Total & 40 & 100.0 \\
\hline
\end{tabular}

Based on the table above, it is found that most respondents have age $>60$ years as many as 24 respondents $(60 \%)$ 


\section{STRADA Jurnal Ilmiah Kesehatan}

DOI: $10.30994 /$ sjik.v9i2.422

ISSN: 2252-3847 (print); 2614-350X (online)

Vol.9 No.2 November 2020 Page.1033-1040

Table 5. Description of Research Variables

\begin{tabular}{lc|c|c|c|c|c} 
& $\mathrm{N}$ & $\begin{array}{c}\text { Minimu } \\
\mathrm{m}\end{array}$ & Maximum & Mean & $\begin{array}{c}\text { Std. } \\
\text { Deviation }\end{array}$ & $\begin{array}{c}\text { Shapiro- } \\
\text { Wilk }\end{array}$ \\
\hline Systolic_pretest & 4 & 140.00 & 220 & 165 & 19.08147 & .011 \\
& 0 & & & & & \\
\hline Diastolic_pretest & 4 & 80.00 & 110 & 93.5 & 6.99817 & .000 \\
\hline Systolic_posttest & 0 & & & & & \\
\hline Diastolic_posttest & 4 & 120.00 & 190 & 148.5 & 17.47526 & .003 \\
& 0 & 70.00 & 110 & 91.5 & 9.48683 & .002 \\
\hline
\end{tabular}

Based on the results of the study, it was found that abnormal normality $(<0.05)$ with the Shapiro-Wilk test, so that the test was reduced to a non-parametric test.

Table 6. Test Statistic

\begin{tabular}{lcc}
\hline Variable & N & P-Value \\
\hline $\begin{array}{l}\text { Systolic blood pressure } \\
\text { (pre-posttest) }\end{array}$ & & 0000 \\
\hline NegativeRanks & 28 & \\
\hline PositiveRanks & 6 & \\
\hline Ties & 6 & \\
\hline Total & 40 & \\
\hline $\begin{array}{l}\text { Diastolic Blood Pressure } \\
\text { (pre-posttest) }\end{array}$ & & \\
\hline NegativeRanks & 12 & \\
\hline PositiveRanks & 8 & \\
\hline Ties & 20 & \\
\hline
\end{tabular}

Wilcoxon statistical test results it was found that there was an influence Beetroot Powder (Beta Bulgaris) Against Decreasing Systolic Blood Pressure in Hypertensive Patients $(\mathrm{p}=0,000)$, and there is no effect of Beetroot Powder (Beta Bulgaris) on Decreasing Diastolic Blood Pressure in Hypertensive Patients $(p=0.293)$,

\section{DISCUSSION}

Based on the table above It was found that most respondents had female gender as many as 38 respondents $(95 \%)$. Based on the table above, it is found that most respondents have age $>60$ years as many as 24 respondents $(60 \%)$. Based on the table above, it is found that most respondents have a job as a domestic helper as many as 34 respondents (85\%). Based on the table above, it is found that most respondents have age $>60$ years as many as 24 respondents $(60 \%)$. Based on the results of the study, it was found that all systolic and diastolic blood pressure variables had an abnormal normality test $(<0.05)$ with the ShapiroWilk test so that the test was reduced to a non-parametric test. Wilcoxon statistical test results showed that there was an influence Beetroot Powder (Beta Bulgaris) on Decreasing Systolic Blood Pressure in Hypertensive Patients $(p=0.000)$, and there is no effect of Beetroot Powder (Beta Bulgaris) on Decreasing Diastolic Blood Pressure in Hypertensive Patients $(\mathrm{p}=0.293)$, 


\section{STRADA Jurnal Ilmiah Kesehatan}

DOI: $10.30994 /$ sjik.v9i2.422

ISSN: 2252-3847 (print); 2614-350X (online)

Vol.9 No.2 November 2020 Page.1033-1040

Hypertension is a condition when systolic blood pressure more than $120 \mathrm{mmHg}$ and diastolic pressure more than $80 \mathrm{mmHg}$. Hypertension often causes changes in blood vessels that can result in higher blood pressure. Early treatment of hypertension is very important because it can prevent complications in several organs of the body, epidemiological investigations have shown that high blood pressure is closely related to cardiovascular disease morbidity and mortality (Muttaqin, 2009). According to (Sutanto, 2010), the cause of hypertension is not yet known with certainty. Hypertension can occur because of the volume of blood pumped by the heart increases, resulting in an increase in the volume of blood in the arteries. In some people with this disease, increased blood pressure is caused by kidney disease. In general, hypertension does not have a specific cause. It is estimated that about 90 percent of hypertensive patients are included in the primary hypertension category. Hypertension is known by 2 types of classifications, including Primary Hypertension and Secondary Hypertension (Pudiastuti, 2011) Primary Hypertension is a condition in which high blood pressure occurs as a result of a person's lifestyle and environmental factors. Someone whose diet is uncontrolled and results in being overweight or even obese is the first trigger for developing high blood pressure. Likewise, someone who is in an environment or high stressor condition is very likely to have high blood pressure, including people who don't exercise too can experience high blood pressure. 2. Secondary hypertension is a condition where there is an increase in high blood pressure as a result of someone experiencing or suffering from other diseases such as heart failure, kidney failure, or damage to the body's hormone system.

Beets contain several active compounds such as carotenoids, glycine betaine, saponins, betacyanin, betanine, polyphenols, and flavonoids (Singh and Hathan, 2013). Beets are rich in carbohydrates that are easy to use as energy and iron, which helps the blood carry oxygen to the brain. Bit red, this color is caused by a combination of the purple pigment betacyanins and the yellow pigment betasantin. Beets are rich in nutrients such as folic acid (growing and replacing damaged cells), potassium (improving fluid balance in the body), vitamin $\mathrm{C}$ (growing tissue and normalizing blood vessels), magnesium (maintaining muscle and nerve function), iron (energy metabolism and immune system), copper (forms red blood cells), phosphorus (strengthens bones), coumarin (prevents tumors) and betacyanin. Beets contain anthocyanins of $51.50 \mathrm{mg} / 100$ grams to $174.70 \mathrm{mg}$ / 100 grams. The pigment contained in beetroot can also give a reddish-purple color which will make the ice cream color more attractive without the addition of synthetic colors (Hanifan, 2016).

The management of hypertension aims to prevent morbidity and mortality due to cardiovascular complications associated with achieving and maintaining blood pressure below 140/90 $\mathrm{mmHg}$. The principles of managing hypertension include Therapy without drugs, but with drugs and follow-up (Padila, 2013). The aim of managing hypertension is to reduce the risk of associated cardiovascular disease. The goal of therapy is to achieve and maintain a systolic pressure below $140 \mathrm{mmHg}$ and a diastolic pressure below 90 $\mathrm{mmHg}$ and control for risk factors. This can be achieved by lifestyle modification (Reny, 2010). Increasing age will cause changes in all organs, especially the cardiovascular system. So that it can be seen that the increasing age increases the risk of hypertension caused by degenerative processes (Syukraini, 2009). This is because arterial pressure increases with age, aortic regurgitation which often occurs in old age. TDS (systolic blood pressure) increases with age, but TDD (diastolic blood pressure) increases with TDS until age 55 years. 


\section{STRADA Jurnal Ilmiah Kesehatan}

DOI: $10.30994 /$ sjik.v9i2.422

ISSN: 2252-3847 (print); 2614-350X (online)

Vol.9 No.2 November 2020 Page.1033-1040

The results of this study indicate that beetroot juice has a significant effect on reducing blood pressure or hypertension. This is because the nutrient content in beets is very complex, including potassium, antioxidants, high calcium, and iron. The content of these nutrients causes a decrease in blood pressure in the elderly. Reducing hypertension can be done by consuming fruits. The intervention given in this study was the provision of beetroot juice. The nutrient highest in beet juice that is intervened is potassium. Consuming high amounts of potassium will increase the concentration in the intracellular fluid, so it tends to draw fluid from the extracellular parts and lower blood pressure. Potassium contained in 100 grams of beets is $10-15 \%$ and is the most abundant nutrient contained in beets. Hypertension does not receive regular treatment or control, it can bring hypertension sufferers into serious cases that can lead to death, high blood pressure that continuously causes a person's heart to work extra hard, eventually this condition results in damage to blood vessels of the heart, kidneys, brain and the eyes as expressed (Pudiastuti, 2011), complications of hypertension, namely stroke can arise due to high pressure bleeding in the brain, myocardial infarction can occur if the coronary arteries with atherosclerosis cannot supply enough oxygen to the myocardium, kidney failure can occur due to damage. progressive due to high pressure in the renal capillaries, glomerular, the inability of the heart to pump blood which returns to the heart rapidly resulting in fluid collecting in the lungs, legs, and other tissues, often called edema, which was started (Triyanto, 2014).

An unhealthy lifestyle, bad habits, and an unhealthy lifestyle, also cause an increase in blood pressure, the factors that cause the appearance of damage to blood vessels also play a role in the appearance of hypertension. These factors include smoking, saturated fatty acid intake, and high cholesterol in the blood, apart from these factors other factors influence the occurrence of hypertension (Sutanto, 2010). According to (Triyanto, 2014), tobacco contains nicotine which strengthens the work of the heart and shrinks small arteries so that blood circulation decreases and blood pressure increases. Quitting smoking is the most powerful lifestyle change for preventing cardiovascular disease in people with hypertension. To quit smoking, it is a difficult step for most people. Especially now that many cigarette factories have sprung up in parts of the archipelago. Smoking plays a very large role in increasing blood pressure, this is due to the nicotine in cigarettes which triggers the adrenal hormone which causes blood pressure to rise. Nicotine is absorbed by the blood vessels in the lungs and circulated throughout the rest of the bloodstream, causing constriction of blood vessels. This causes the work of the heart to increase to pump blood throughout the body through narrow blood vessels. The giving of rewards and punishments by the family to reduce smoking behavior at community meetings should be posted on a smoking ban poster in every house. Most smoking is done by men, so the wife must be able to motivate her partner to quit smoking. Through health promotion activities and forms of clean and healthy living habits in which there is an indicator of no smoking in the house, it should be emphasized that smoking is completely prohibited.

\section{CONCLUSION}

The results showed that there was an influence Beetroot Powder (Beta Bulgaris) on Decreasing Systolic Blood Pressure in Hypertensive Patients $(p=0,000)$, and there is no effect of Beetroot Powder (Beta Bulgaris) on Decreasing Diastolic Blood Pressure in Hypertensive Patients $(\mathrm{p}=0.293)$, 


\section{STRADA Jurnal Ilmiah Kesehatan}

DOI: $10.30994 /$ sjik.v9i2.422

ISSN: 2252-3847 (print); 2614-350X (online)

Vol.9 No.2 November 2020 Page.1033-1040

\section{REFERENCES}

Anggara dkk, (2012). Faktor-Faktor Yang Berhubungan Dengan Tekanan Darah Di Puskesmas Telaga Murni, Cikarang Barat Tahun 2012. Program studi S1 Kesehatan Masyarakat STIKES MH Thamrin

Astuti VW, Suwardianto H (2016) PENGETAHUAN GURU TAMAN KANAK-KANAK TENTANG ALAT PERMAINAN EDUKATIF DI TAMAN KANAK-KANAK BAPTIS SETIA BAKTI KEDIRI. J. STIKES RS Baptis Kediri 9:

Korneliani, K., dan Meida, D. (2012). Hubungan obesitas dan stress dengan hipertensi pada guru SD wanita. Jurnal Kesehatan Masyarakat, 7 (2): 111-115.

Kresnawan, T. (2011). Asuhan Gizi Hipertensi. Jurnal Gizi Indon 2011, 34(2): 143-147. Lestari, AP. dan Rahayuningsih, HM. (2012). Pengaruh pemberian jus tomat

Muttaqin, 2009. Asuhan Keperawatan Klien Denga Kardiovaskuler. Jakarta : Penerbit Salemba Medika

Oktavianus, \& Sari, Febriani Sartika, (2014). Asuhan Keperawatan Pada Sistem Kardiovaskuler Dewasa. Yogyakarta : Graha Ilmu

Padila, (2013). Buku Ajar Keperawatan Gerontik. Yogyakarta : Nuha Medika

Priambodo dkk, (2010).Gambaran Faktor-faktor Kepatuhan Diet Lanjut Usia Penderita Hipertensi. RS PKU Muhammadiyah Gamping Sleman

Ramayulis, R. (2016). Diet untuk Penyakit Komplikasi. Jakarta: Penebar Plus. 18. Rizki, F. (2013). The Miracle of Vegetables. Jakarta: PT Agro Media Pustaka.

Shanty, Meita, (2011). Silent Killer Diseases. Yogyakarta : Javalitera

Susilo, Yekti, \& Wulandari, Ari, (2011). Cara Jitu Mengatasi Hipertensi. Yogyakarta : ANDI

Sutanto. (2010), Cekal (Cegah \& Tangkal) Penyakit Modern. Yogyakarta : Andi

Sutomo, Budi, (2009). Menu Sehat Penakuk Hipertensi. Jakarta Selatan : DeMedia Pustaka

Suwardianto H (2012) Pengaruh tehnk relaksasi nafas dalam (deep Breathing) terhadap perubahan tekanan darah pada penderita hipertensi di Puskesmas Kota Wilayah Selatan Kediri.

Suwardianto H (2016) Tardive dyskenesia, motor activity, sedation scale, dan cardiac workload pasien IPI pada pemberian analgesik di instalasi perawatan intensif RS. baptis kediri. Keperawatan Krit. Penelit. Hibah YBI

Suwardianto H (2017) PENGETAHUAN, SIKAP DAN PERILAKU PENCEGAHAN DEKUBITUS PADA KELUARGA DENGAN IMOBILISASI. Pros. Semin. Nas. dan Work. Publ. Ilm.

Suwardianto H (2018) Level Of Perception Emergency Skills In Youth Red Cross. J Nurs Pract 2:17-24

Suwardianto H, Prasetyo A, Utami RS (2017) Phisical Function (Motor Activity) Pada Pasien Kritis Dengan Sedation Di Intensive Care Unit. J Ilmu Kesehat 5:91-102

Suwardianto H, Prasetyo A, Utami RS (2018) Effects of Physical-Cognitive Therapy (PCT) on Criticaly ill Patients in Intensive Care Uni. Hiroshima J Med Sci 67:6369

Suwardianto H, Rimawati (2018) Explicit Instruction Model (EIM): Daily Training Emergencies Preparedness (DTEP) Toward Skills of Participants the Youth Red Cross. Conf 2nd Jt Int 2:403-410

Suwardianto H, Sari D (2020) Environmental Factors of Sleep Hygiene That Influence The Level of Pain on Criticall ill Patients in Intensive Care Unit. Str J Ilm Kesehat. https://doi.org/10.30994/sjik.v9i1.266 


\section{STRADA Jurnal Ilmiah Kesehatan}

DOI: $10.30994 /$ sjik.v9i2.422

ISSN: 2252-3847 (print); 2614-350X (online)

Vol.9 No.2 November 2020 Page.1033-1040

Suwardianto H, Sari DAKW (2019) Pain Level in Critical Patients With Sleep Hygiene Care In Intensive Care Unit. J Nurs Pract. https://doi.org/10.30994/jnp.v3i1.61

Suwardianto H, Selvia D (2015) Buku Ajar Keperawatan Kegawatdaruratan (Perspektif, Konsep, Prinsip, dan Penatalaksanaan Kegawatdaruratan). PT. REVKA PETRA MEDIA, Surabaya

Suwardianto H, YC A (2016) Kemandirian Fungsional Lansia Diabetes Melitus Di Kelurahan Bangsal Kota Kediri. J. STIKES RS Baptis Kediri 9:

Thomson, J., Manore, M., dan Voughan, L. (2011). Science of Nutrition 2nd ed. USA: Pearson Education Inc.

Triyanto, Endang, (2014). Pelayanan Keperawatan Penderita Hipertensi Secara Terpadu. Yogyakarta : Graha Ilmu

Webb, A. J., Patel, N., Loukogeorgakis, S., Okorie, M., Aboud, Z., \& Misra, S. (2008). Acute Blood Pressure Lowering, Vasoprotective, and Antiplatelet Properties of Dietary nitrate via Bioconversion to Nitrite. American Heart Association, 784-790. 